\title{
CHANGES IN THE TROPHIC STRUCTURE OF THE VERTEBRATE PREDATOR COMMUNITY IN THE COLD SEASON IN BELARUSSIAN PAAZERJE (NORTHERN BELARUS) WITH EMPHASIS ON DEPOPULATION OF THE WILD BOAR, SUS SCROFA (ARTIODACTYLA, SUIDA)
}

\author{
V. V. Ivanovskij ${ }^{1}$, A. A. Sidorovich ${ }^{2}$, I. A. Solovej ${ }^{3}$ \\ ${ }^{1}$ Vitebsk State University named after P. M. Masherov, \\ Moskovskij Ave., 33, Vitebsk, 210038 Belarus \\ E-mail:ivanovski@tut.by \\ ${ }^{2}$ Scientific and Practical Center for Bioresources of NAS of Belarus \\ Akademicheskaja str., 27, Minsk, 220072 Belarus \\ E-mail:anna-ecofox@mail.ru \\ ${ }^{3}$ Scientific and Practical Center for Bioresources of NAS of Belarus \\ Akademicheskaja str., 27, Minsk, 220072 Belarus \\ E-mail: soloveji@tut.by
}

A. A. Sidorovich (https://orcid.org/0000-0001-7523-5048)

\begin{abstract}
Changes in the Trophic Structure of the Vertebrate Predator Community in the Cold Season in Belarussian Paazerje (Northern Belarus) with Emphasis on Depopulation of the Wild Boar, Sus scrofa (Artiodactyla, Suida). Ivanovskij, V. V., Sidorovich, A. A., Solovej, I. A. - Anthropogenic disturbances often alter patterns of community functioning. Along that, how interacting species respond to these changes remains poorly understood. In 1972-2019, we studied the trophic structure of the vertebrate predator community in coniferous-small-leaved forests of Belarussian Paazerje (Northern Belarus). Since 2013, large scale depopulation of Wild Boars, Sus scrofa, has been started in Belarus as a measure to reduce a circulation of the African swine fever (ASF). It was found that the community consisted of four trophic guilds including small rodent consumers, bird consumers, scavengers, and ungulate consumers. The pronounced shift $\mathrm{s}$ in dietary compositions of three scavengers (the Raccoon Dog, Nyctereutes procyonoides, Golden Eagle, Aquila chrysaetos and White-tailed Eagle, Haliaeetus albicilla) after a decrease in an abundance of Wild Boar carrion was revealed. Along that, the average value of the dietary similarity between investigated species stayed the same.

K e y w or d s : community structure, vertebrate predators, dietary composition, Wild Boar depopulation, Belarus.
\end{abstract}




\section{Introduction}

The analysis of competitive relationships in the multi-species community of vertebrate predators and their prey was conducted in several studies (Levins, 1968; Matveev et al., 1988; Krebs, 1999; Kataev, Okulova, 2007; Sidorovich, 2016). And still a lot of open questions exist in relation to particular patterns of food resource partitioning and its seasonal and multiannual dynamics, especially in conditions of unexpected human impacts on natural environments.

The African swine fewer (ASF) was firstly officially recognized in Belarus in 2013. And right after that state and private hunting estates started large-scale depopulation of Wild Boars, Sus scrofa Linnaeus, 1758, as a preventive measure. As a result, the Wild Boar numbers declined from 80.4 thousand in 2013 to 2.6 thousand in 2018. Two species of large predators (the Grey Wolf, Canis lupus Linnaeus, 1758 and Eurasian Lynx, Lynx lynx Linnaeus, 1758), predate on Wild Boars in winter time, and six species of vertebrate predators (the Raccoon Dog, Nyctereutes procyonoides Gray, 1834, Golden Eagle, Aquila chrysaetos Linnaeus, 1758, White-tailed Eagle, Haliaeetus albicilla Linnaeus, 1758, Red Fox, Vulpes vulpes Linnaeus, 1758, Pine Marten, Martes martes Linnaeus, 1758, and Rough-legged Buzzard, Buteo lagopus Pontoppidan, 1763), consume Wild Boar carrion in the cold season constantly (Sidorovich, 2016; Ivanovskij et al., 2019).

The goal of this study was to analyze the trophic structure of the vertebrate predator community in the cold season in coniferous-small-leaved forests of Belarussian Paazerje and reveal possible changes caused by depopulation of Wild Boars.

Such reduction of food supply may cause cascade ecological effects. The winter is the harshest period in the life of predators in Northern hemisphere. Food supply is very limited due to low abundance and difficult access to food resources. Any shifts in food resource availability will impact not only on a dietary composition of the species but also may lead to significant functional and structural changes in the whole vertebrate predators' community.

The study is a part of interrelated projects on feeding habits of vertebrate predators in Belarus (Jaksic et al., 1981; Jedrzejewska, Jedrzejewski, 1998; Sidorovich, 2016; Ivanovskij et al., 2019).

\section{Material and methods}

Study area

The study was conducted in Northern Belarus where mixed coniferous-small-leaved forests are prevailed. This region is traditionally called Belarussian Paazerje (Lakeland) and comprises Vitebsk Region and some northern districts of Minsk and Grodno Regions. Central and Western parts of the territory is occupied by the Polotsk lowland. The climate of the territory is humid continental. Compared to the rest country, Belarussian Paazerje has more severe climate conditions. The average temperature in January is $-6.5-7.0{ }^{\circ} \mathrm{C}$. The territory belongs mainly to the basin of the Zakhadnaya Dzvina River (81\%) and is characterized by a relatively dense hydrographic network with a huge number of postglacial lakes (about 2.8 thousand) of different size. Lakes cover $2.5 \%$, in some areas (Braslavsky and Ushachsky Districts) up to $10 \%$.

Belarussian Paazerje belongs to the European forest zone (subzone of transitional mixed coniferoussmall-leaved forests). Forest cover comprises $39.8 \%$. Wetlands occupy about $9 \%$ of the territory and vary from open grassy marshes to pine bogs and swamped black alder forests. In relation to fauna composition, Belarussian Paazerje belongs to the European-Siberian subarea of the Palearctic ecoregion. About 462 species of vertebrate animals inhabit its territory: 72 species of mammals, more than 58 species of fish, 19 species of amphibians and reptiles, about 236 species of nesting birds and 33 species on migrations or wintering.

\section{Diet composition}

The dietary composition of 17 vertebrate predators in the region ( 5 species of birds of prey, 6 carnivorous mammals and 6 owls) was studied by visual observations and an analysis of prey remains, pellets and scats. Five birds of prey (the Golden and Wite-tailed Eagles, Goshawk, Accipiter gentilis Linnaeus, 1758, Sparrowhawk, Accipiter nisus Linnaeus, 1758, Rough-legged Buzzard) and six owls (the Eurasian Pygmy Owl, Glaucidium passerinum Linnaeus, 1758, Tengmalm's Owl, Aegolius funereus Linnaeus, 1758, Tawny Owl, Strix aluco Linnaeus, 1758, Ural Owl, Strix uralensis Pallas, 1771, Great Grey Owl, Strix nebulosi J. R. Forster, 1772, and Eurasian Eagle Owl, Bubo bubo Linnaeus, 1758), stay in Belarussian Paazerje for overwintering. Among mammalian predators, the Wolf, Pine Marten, Red Fox, and Weasel, Mustela nivalis Linnaeus, 1766, are common and numerous there. The Raccoon Dog stays active when the conditions are not very cold. The population numbers of the Eurasian Lynx is increasing but still remains low.

Rare species with low population densities were excluded from the analysis. The taxonomic identification of osteological material, feathers and skin scales of amphibians, reptilians and birds was done by comparing with a control collection and using special keys (Cramp, Simmons, 1980; Böhme, 1977; März, 1987; Brown et al., 1999; Sidorovich, 2014). The identification of mammals from pellets and scats was carried out by two methods: by skulls, teeth, and other parts of the skeleton (Pucek, 1981) and by the microscopic structure of ten hairs that were randomly taken from a pellet or scat (Debrot et al., 1982; Teerink, 1991). The number of specimens of the same small mammal species in a pellet was estimated by the number of similar skeletal remains and using known weights of a hair coat for different species (Sidorovich, 2014). Insects were distinguished by the remains of exoskeleton. A total of 2,339 feeding samples (pellets, scats and prey remains) are gathered in 1972-2019 in semi-natural forests 
on Belarussian Paazerje. 6,307 prey individuals were identified.In addition, published data of V. E. Sidorovich (Sidorovich, 2011) on diets of the Weasel, Pine Marten, Pygmy Owl, Ural Owl, Great Grey Owl, Eagle-Owl, and Sparrowhawk before 2013 were used to complete the analysis.

To investigate the feeding behavior of predators near carrion, more than 50 hours of observations from a special shelter were carried out.

To obtain the percentage of food biomass consumed (hereafter, \% BC) for carnivorous mammals, we followed the approach based on the coefficients of digestibility (the ratio of fresh weight of a given food item to the dry weight of its remains in a feeding sample. The sources of the digestibility coefficients were Reynolds and Aebischer (1991), Jędrzejewska and Jędrzejewski (1998) and the references therein. For birds of prey calculations was done in different way. The number of prey individuals was multiplied by the mean body mass of that prey (Pucek, 1981; Sidorovich, 2014). If a weight of a given prey or another food item (in the case of carrion consumption) is higher than the weight of average daily food intake of the species, we used the latter value in the calculations.

Each researcher who deals with trophic structure of the community always faces a dilemma: how many food categories to divide out of all diversity of food items. A very detailed division can lead to the fact that behind a dense "forest" of dendrograms researches may not see a pair of connected "branches". From other hand, the splitting into larger food categories may lead to a very high similarity between species. As a "golden mean", we group all food items into 19 categories in accordance with consumption pattern (predation, scavenging, gathering) and a prey body mass.

Dietary diversity (trophic niche breadth) was assessed by the Levins' index B (Levins, 1968):

$$
\mathrm{B}=1 / \sum \mathrm{p}_{\mathrm{i}}^{2}
$$

where $p_{i}-$ fraction food item $i$ is of the total biomass consumed by the predator.

The simplified Morisita's index $C_{H}$ (after Krebs. 1999) was used to compare diets:

$$
\mathrm{C}_{\mathrm{H}}=\frac{2 \sum_{i}^{n} \mathrm{p}_{\mathrm{ij}} \mathrm{p}_{\mathrm{ik}}}{\sum_{i}^{n} \mathrm{p}^{2}{ }_{\mathrm{ij}}+\sum_{i}^{n} \mathrm{p}^{2}{ }_{\mathrm{ik}}},
$$

where $p_{i j}$ - fraction food item $i$ is of the total biomass consumed by Common Buzzards in the study area $j$; $p_{i k}$ - fraction food item $i$ is of the total biomass consumed by Common Buzzards in the study area $k ; i=1,2$, $3, \ldots, n ; n-$ total number of food items. The index varies between 0 (exclusive niches) and 1 (complete overlap). To assess the trophic structure of the community and reveal trophic guilds we applied the cluster analysis using the Morisita's index as a proxy of similarity.

The replicated goodness-of-fit test (G-statistic) was used to examine the heterogeneity of percentages and reveal significant differences between diet compositions (Sokal, Rohlf ,1995).

Statistical analysis

Statistical calculations were carried out using ASPID/GT software (Grigyantz, 1993 ) according to the recommendations given by Sokal and Rohlf (1995). Cluster analysis was performed in PAST software (release 3.06) by the method of unweighted double mean (UPGMA), using the Morisita's index as a measure of similarity.

\section{Results and discussion}

The trophic structure of the vertebrate predator community

Our study showed that in coniferous-small-leaved forests of Belarussian Paazerje, vertebrate predators consumed all taxa of vertebrate animals as well as a wide range of insects and other invertebrates. In 1982-2011, the most important items in their diets were small rodents, ungulate carrion, and medium-sized animals (table 1-3). The food niche breadth, assessed with Levins' index (B), ranged from 1.0 to 4.6.

The values of Morisita's index of similarity varied from 0 to 0.99 (table 4). Complete dissimilarity $\left(C_{H}=0\right)$ was found for 11 pairs of species. Low dietary overlap $\left(C_{H}<0.33\right)$ was attributable for 54 pairs of species, medium $\left(0,33<C_{H}<0.66\right)$ for 26 pairs of species, and high $\left(C_{H}>0.66\right)$ for 40 pairs of species. The average value of the trophic similarity for the community was moderate and equaled 0.37 .

In accordance with cluster analysis, the community of vertebrate predators in forest ecosystems consisted offour pronounced clusters (trophic guilds) with the level of similarity inside clusters is higher than 0.5 (fig. 1). The largest trophic guild (cluster 1) comprised nine small mammal consumers: the Tengmalm's Owl, Weasel, Rough-legged Buzzard, Ural Owl, Great Grey Owl, Tawny Owl, Eagle-Owl, Pine Marten, and Red Fox. The portion of small mammals in the diets of these predators varied from 38.9 to $88.9 \%$ BC. The Pine Marten 
T a b l e 1. Dietary composition (\% BC) of mammalian predators in the cold season in coniferoussmall-leaved forests of Belarussian Paazeje, Northern Belarus, 1982-2011

\begin{tabular}{|c|c|c|c|c|c|c|}
\hline Food items & Weasel $^{*}$ & $\begin{array}{c}\text { Pine } \\
\text { Marten }^{*}\end{array}$ & $\begin{array}{c}\text { Raccon } \\
\text { Dog }\end{array}$ & $\begin{array}{l}\text { Red } \\
\text { Fox }\end{array}$ & $\begin{array}{c}\text { Eurasian } \\
\text { Lynx }^{*}\end{array}$ & $\begin{array}{l}\text { Grey } \\
\text { Wolf* }\end{array}$ \\
\hline Invertebrates & 0.1 & 4.8 & 2.6 & 0.1 & - & - \\
\hline Fish & - & - & 0.5 & - & - & - \\
\hline Amphibians and reptiles & 0.7 & 1.7 & 0.9 & 0.2 & - & - \\
\hline Small insectivores & 7.1 & 6.1 & 0.4 & 0.4 & - & - \\
\hline Small rodents, among them: & 86.5 & 38.9 & 1.7 & 46.4 & 8.1 & 0.1 \\
\hline Microtus voles & 20.1 & 3.4 & 1.1 & 29.0 & 5.1 & 0.1 \\
\hline Sylvaemus mice & 2.1 & 7.0 & 0.1 & 1.6 & - & - \\
\hline Bank Vole & 62.8 & 22.2 & 0.5 & 8.8 & - & - \\
\hline Water Vole & 1.5 & - & - & 1.9 & _- & - \\
\hline Other small rodent species & - & 6.3 & - & 5.1 & 3.0 & - \\
\hline Squirrel, Muskrat and Hedgehog & - & 6.3 & 1.7 & 5.1 & 3.0 & - \\
\hline Hares & - & 1.1 & 0.4 & 13.4 & 45.7 & 2.7 \\
\hline Beaver & - & - & - & - & 0.5 & 3.5 \\
\hline Wild ungulates, among them: & - & - & - & - & 24.4 & 87.0 \\
\hline Roe Deer & - & - & - & - & 21.4 & 7.9 \\
\hline Elk & - & - & - & - & - & 28.3 \\
\hline Wild Boar & - & - & - & - & 3.0 & 50.8 \\
\hline Small mustelids & - & - & 0.2 & 0.4 & - & - \\
\hline Medium-sized mustelids & - & - & 0.3 & 1.6 & 1.3 & - \\
\hline Red Fox and Raccoon Dog & - & - & - & - & 4.4 & 4.0 \\
\hline Domestic animals & - & - & - & - & 1.2 & 2.4 \\
\hline Carrion of wild animals, among them: & - & 21.6 & 58.3 & 28.5 & - & - \\
\hline Beaver Carrion & - & 0.1 & - & 4.8 & - & - \\
\hline Carrion of Cervids & - & 21.4 & 39.0 & 18.4 & - & - \\
\hline Wild Boar Carrion & - & 0.1 & 19.3 & 5.3 & - & - \\
\hline Small birds & 2.8 & 3.9 & 0.4 & 0.9 & 0.9 & - \\
\hline Medium-sized and big birds & - & 4.0 & 1.8 & 2.9 & 13.4 & 0.1 \\
\hline Bird eggs & - & 0.5 & - & - & - & - \\
\hline Seeds, fruits and vegetables & - & 11.1 & 20.3 & 0.1 & 0.1 & 0.2 \\
\hline Other & - & - & 10.5 & - & - & - \\
\hline Number of food specimens (n) in the analysed & $\begin{array}{c}190 \\
(178)\end{array}$ & $\begin{array}{c}604 \\
(243)\end{array}$ & $\begin{array}{l}1270 \\
(397)\end{array}$ & $\begin{array}{r}2186 \\
(465)\end{array}$ & $\begin{array}{c}425 \\
(250)\end{array}$ & $\begin{array}{l}1052 \\
(620)\end{array}$ \\
\hline Levins' index $(B)$ of food niche breadth & 1.33 & 4.47 & 2.54 & 3.14 & 2.08 & 1.54 \\
\hline
\end{tabular}

${ }^{\star}$ Diets of the predators are taken from Sidorovich et al., 2011.

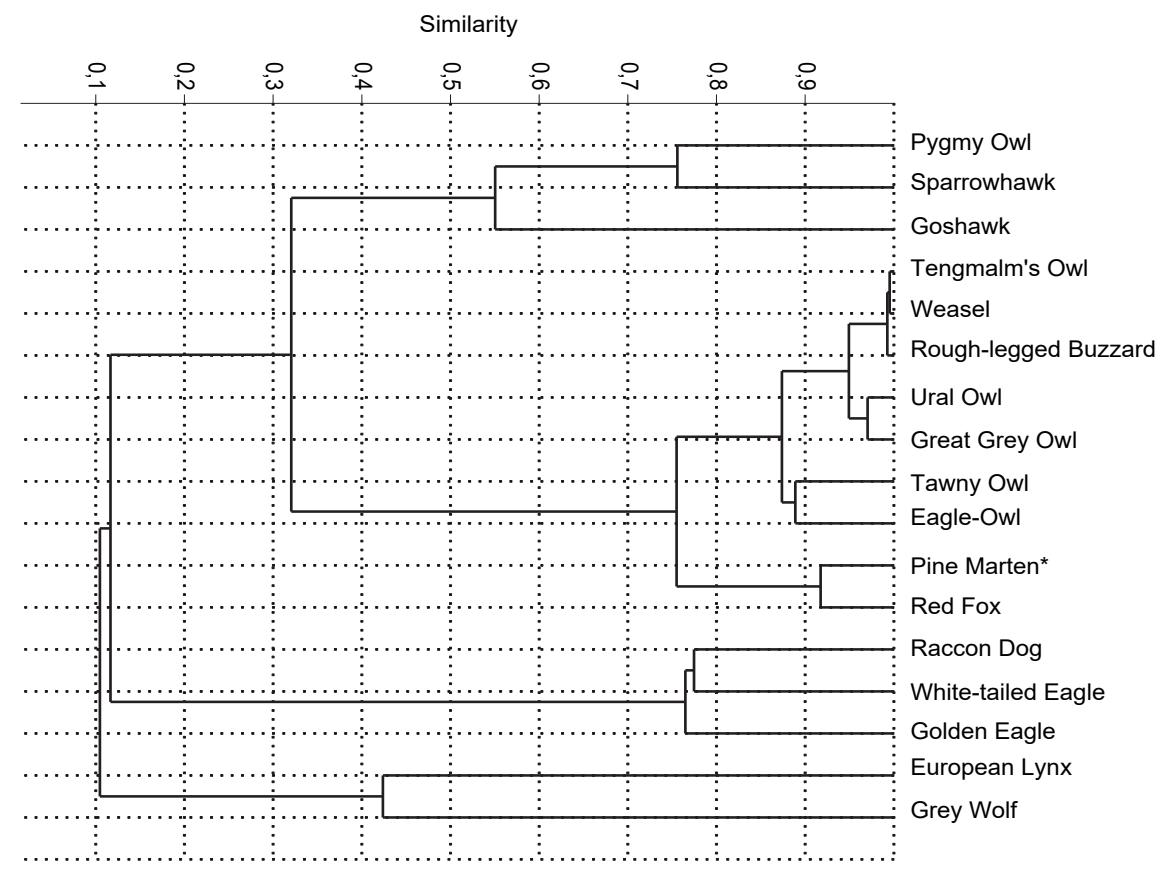

Fig. 1. Dietary similarity of 17 vertebrate predators in the cold season in Belarussian Paazerje, 1972-2012. 
Table 2. Dietary composition (\% BC) of owls in the cold season in coniferous-small-leaved forests of Belarussian Paazeje, Northern Belarus, 1982-2011

\begin{tabular}{|c|c|c|c|c|c|c|}
\hline Food items & $\begin{array}{l}\text { Pygmy } \\
\text { Owl }^{\star}\end{array}$ & $\begin{array}{l}\text { Tengmalm's } \\
\text { Owl }\end{array}$ & $\begin{array}{l}\text { Tawny } \\
\text { Owl }^{*}\end{array}$ & $\begin{array}{l}\text { Ural } \\
\text { Owl }^{*}\end{array}$ & $\begin{array}{c}\text { Great } \\
\text { Grey Owl }^{*}\end{array}$ & $\begin{array}{l}\text { Eagle- } \\
\text { Owl }^{\star}\end{array}$ \\
\hline Invertebrates & - & 0.1 & 3.8 & - & - & - \\
\hline Fish & - & - & - & - & - & - \\
\hline Amphibians and reptiles & - & - & 14.0 & 1.7 & - & 1.0 \\
\hline Small insectivores & 2.5 & 1.3 & 13.8 & 8.5 & 2.3 & 5.6 \\
\hline Small rodents, among them: & 41.3 & 95.7 & 53.6 & 64.9 & 75.8 & 54.1 \\
\hline Microtus voles & 1.7 & 10.7 & 22.9 & 11.2 & 38.4 & 3.6 \\
\hline Sylvaemus mice & 13.4 & 6.2 & 6.6 & 8.6 & 4.6 & 0.9 \\
\hline Bank Vole & 25.0 & 73.1 & 24.1 & 29.0 & 2.1 & 0.7 \\
\hline Water Vole & - & 5.7 & - & 6.9 & 30.7 & 48.4 \\
\hline Other small rodent species & 1.2 & - & - & 9.2 & - & 0.5 \\
\hline Squirrel, Muskrat and Hedgehog & - & - & - & 9.2 & 0.5 & 0.5 \\
\hline Hares & - & - & - & 3.0 & 4.9 & 21.8 \\
\hline Beaver & - & - & - & - & - & - \\
\hline Wild ungulates, among them: & - & - & - & - & - & - \\
\hline Roe Deer & - & - & - & - & - & - \\
\hline Elk & - & - & - & - & - & - \\
\hline Wild Boar & - & - & - & - & - & - \\
\hline Small mustelids & - & - & 4.7 & 5.5 & 13.1 & 10.4 \\
\hline Medium-sized mustelids & - & - & - & - & 0.3 & 0.5 \\
\hline Red Fox and Raccoon Dog & - & - & - & - & - & - \\
\hline Domestic animals & - & - & - & - & - & - \\
\hline Carrion of wild animals, among them: & - & - & - & - & - & - \\
\hline Beaver Carrion & - & - & - & - & - & - \\
\hline Carrion of Cervids & - & - & - & - & - & - \\
\hline Wild Boar Carrion & - & - & - & - & - & - \\
\hline Small birds & 56.2 & 2.9 & 3.6 & 3.0 & - & 0.6 \\
\hline Medium-sized and big birds & - & - & 6.5 & 4.2 & 3.1 & 5.5 \\
\hline Bird eggs & - & - & - & - & - & - \\
\hline Seeds, fruits and vegetables & - & - & - & - & - & - \\
\hline Other & - & - & - & - & - & - \\
\hline Number of food specimens ( $n$ ) in the & 109 & 104 & 324 & 41 & 184 & 226 \\
\hline analysed samples (m), n (m) & $(52)$ & $(83)$ & $(62)$ & $(41)$ & $(42)$ & $(26)$ \\
\hline Levins' index $(B)$ of food niche breadth & 2.05 & 1.09 & 2.98 & 2.25 & 1.68 & 2.80 \\
\hline
\end{tabular}

${ }^{\star}$ Diets of the predators are taken from Sidorovich et al., 2011.

and Red Fox formed separate sub-cluster within cluster 1 due to frequent consumption of ungulate carrion. A dietary similarity between small mammal consumers was much higher than between species in other guilds.

Two guilds consisted of three species each. The guild of scavengers (cluster 2) included the Raccoon Dog, White-tailed and Golden Eagles in whose diets mammalian carrion constituted not less than 40 \% BC. Birds prevailed in diets of the Goshawk, Sparrowhawk and Pygmy Owl (cluster 3), and were important additional food stuff for the rest predators. The Wolf and Lynx represented the guild of ungulate consumers.

\section{Behavioral patterns of scavengers near mammalian carrion}

We examined a behavior of five taxonomic predatory species (the Wite-tailed Eagle, Golden Eagle, Red Fox, Pine Marten and Raccoon Dog) and one non-taxonomic predatory species (the Common Raven, Corvus corax Linnaeus, 1758) while feeding on the carrion. Simultaneous presence and feeding on carrion was registered for avian scavengers at day time. The Golden and White-tailed Eagles regularly conflicted over carrion (fig. 2), and the raven just tried to grab a piece of meat during these encounters. Mammalian scavengers ate mostly when avian predators flew away or came to carrion at night. We also found no physical collisions between mammalian scavengers.

Consumption on carrion in winter conditions has negative consequences for the White-tailed and Golden Eagles. They suffered from traps set by hunters at carrion to Catch Wolves, Red Foxes, Raccoon Dogs and Pine Martens (fig. 3). During the study period (1972-2019), we revealed 46 White-tailed Eagles and 37 Golden Eagles caught in a trap and died. 
Table 3. Dietary composition (\% BC) of birds of prey in the cold season in coniferous-small-leaved forests of Belarussian Paazeje, Northern Belarus, 1982-2011

\begin{tabular}{|c|c|c|c|c|c|}
\hline Food items & $\begin{array}{c}\text { Sparrow- } \\
\text { hawk }^{*}\end{array}$ & Goshawk & $\begin{array}{c}\text { Rough-legged } \\
\text { Buzzard }\end{array}$ & $\begin{array}{c}\text { Golden } \\
\text { Eagle }\end{array}$ & $\begin{array}{l}\text { White-tailed } \\
\text { Eagle }\end{array}$ \\
\hline Invertebrates & - & - & 0.1 & - & - \\
\hline Fish & _- & _- & - & _- & 27.8 \\
\hline Amphibians and reptiles & - & 0.1 & - & - & - \\
\hline Small insectivores & - & - & 0.7 & - & - \\
\hline Small rodents, among them: & _- & 16.0 & 88.9 & 0.8 & _ \\
\hline Microtus voles & - & 2.1 & 80.4 & - & - \\
\hline Sylvaemus mice & _ & 1.5 & 7.0 & _ & _ \\
\hline Bank Vole & - & 9.9 & 1.4 & _ & _ \\
\hline Water Vole & - & - & - & - & _- \\
\hline Other small rodent species & - & 2.5 & 0.1 & 0.8 & - \\
\hline Squirrel, Muskrat and Hedgehog & - & 13.4 & - & 0.8 & 0.3 \\
\hline Hares & - & 5.3 & 7.8 & 24.8 & 3.0 \\
\hline Beaver & - & - & - & 6.4 & - \\
\hline Wild ungulates, among them: & - & - & - & _- & - \\
\hline Roe deer & _ & _ & _- & 1.9 & _ \\
\hline Elk & _- & _- & _- & _- & _ \\
\hline Wild Boar & - & - & - & - & - \\
\hline Small mustelids & _- & 1.4 & _- & _ & _ \\
\hline Medium-sized mustelids & - & 0.7 & - & 2.2 & 6 \\
\hline Red Fox and Raccoon Dog & _ & 0 & _ & 5.8 & 8.3 \\
\hline Domestic animals & - & 2.3 & - & 0.8 & 0 \\
\hline Carrion of wild animals, among them: & - & 2.6 & 2.5 & 42.7 & 46.1 \\
\hline Beaver Carrion & _- & - & - & _- & - \\
\hline Carrion of Cervids & - & 2.6 & 1.0 & 21.3 & 25.6 \\
\hline Wild Boar Ccarrion & _ & - & 1.5 & 21.4 & 20.5 \\
\hline Small birds & 100 & 28.2 & - & 1.2 & - \\
\hline Medium-sized and big birds & - & 30.0 & - & 12.6 & 8.5 \\
\hline Bird eggs & - & - & - & - & - \\
\hline Seeds, fruits and vegetables & - & - & - & - & - \\
\hline Other & - & - & - & - & - \\
\hline $\begin{array}{l}\text { Number of food specimens }(n) \text { in the } \\
\text { analysed samples }(m), n(m)\end{array}$ & $339(66)$ & $108(65)$ & $515(264)$ & $116(81)$ & $158(63)$ \\
\hline Levins' index $(B)$ of food niche breadth & 1.00 & 4.60 & 1.25 & 3.73 & 3.24 \\
\hline
\end{tabular}

${ }^{\star}$ Diets of the predators are taken from Sidorovich et al., 2011

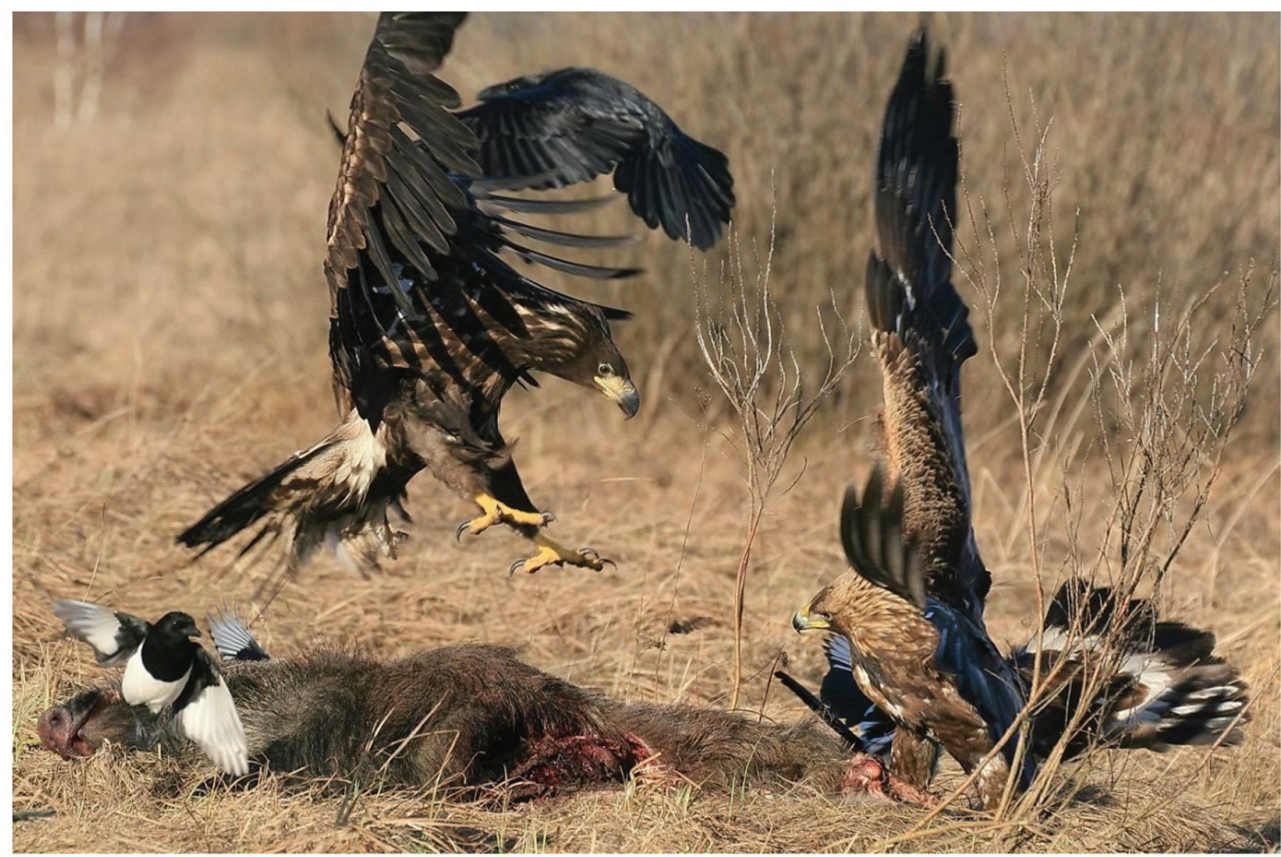

Fig. 2. The Golden and White-tailed Eagles feed regularly on carrion and physical interference takes place quite often. 


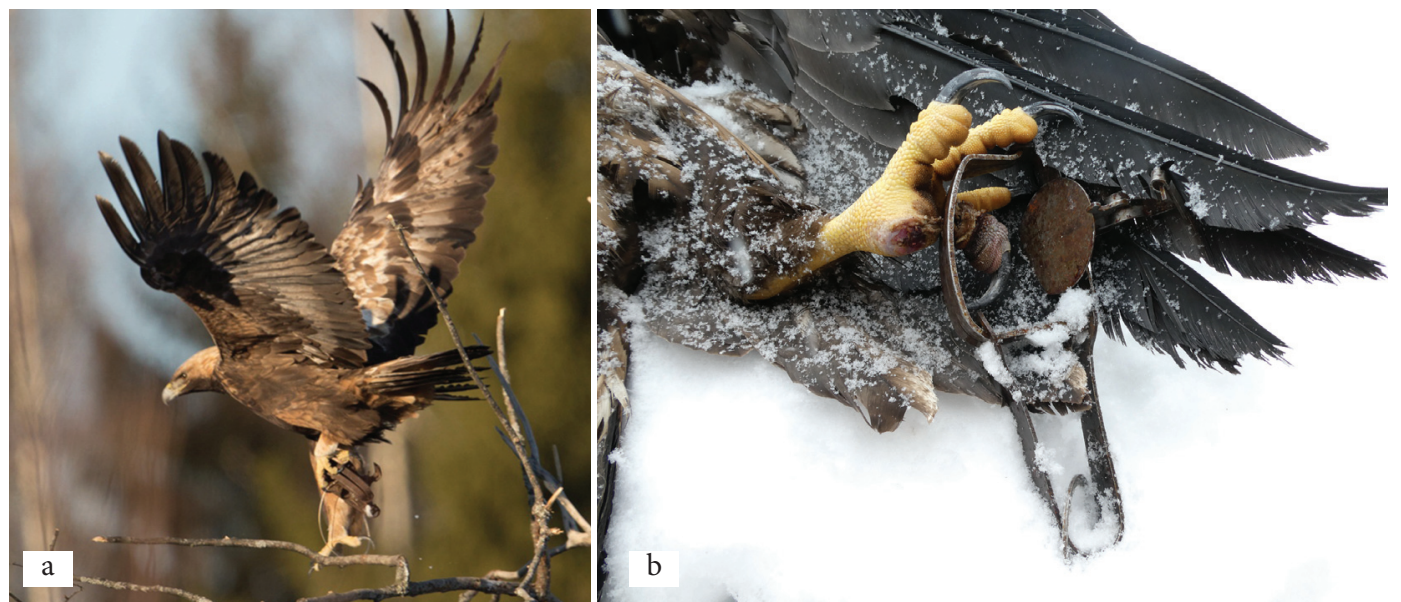

Fig. 3. The Golden (a) and White-tailed (b) Eagles suffered from traps set by hunters at Carrion to Catch Wolves, Red Foxes, Raccoon Dogs and Pine Martens. Photos by Ronald Jan Huijssen (a) and Ugis Bergmanis (b).

Table 4. Dietary overlaps (the Morisita's index) between vertebrate predators in the cold season in coniferous-small-leaved forests of Belarussian Paazerje, Northern Belarus, upper right corner - before a depopulation of the Wild Boar (1982-2011), bottom left corner - after a large-scale depopulation of the Wild Boar (2013-2019)

\begin{tabular}{|c|c|c|c|c|c|c|c|c|c|c|c|c|c|c|c|c|c|}
\hline Species & $\mathrm{Mm}^{\star *}$ & $\mathrm{~Np}$ & Vv & Af & $\mathrm{Sa}$ & An & $\mathrm{Ag}$ & $\mathrm{Bl}$ & $\mathrm{Ha}$ & Ach & $\mathrm{Mn}$ & $\mathrm{Ll}$ & $\mathrm{Cl}$ & $\mathrm{Gp}$ & $\mathrm{Su}$ & Sn & $\mathrm{Bb}$ \\
\hline $\mathrm{Mm}$ & & 0.39 & 0.96 & 0.78 & 0.88 & 0.06 & 0.45 & 0.82 & 0.34 & 0.36 & 0.70 & 0.17 & 0 & 0.58 & 0.87 & 0.85 & 0.84 \\
\hline $\mathrm{Np}$ & 0.42 & & 0.50 & 0.03 & 0.04 & 0.01 & 0.09 & 0.05 & 0.78 & 0.77 & 0.03 & 0.02 & 0 & 0.02 & 0.11 & 0.03 & 0.03 \\
\hline $\mathrm{VV}_{\mathrm{V}}^{\mathrm{T}}$ & 0.93 & 0.56 & & 0.73 & 0.77 & 0.01 & 0.41 & 0.79 & 0.44 & 0.55 & 0.75 & 0.34 & 0.01 & 0.50 & 0.79 & 0.80 & 0.84 \\
\hline Af & 0.81 & 0.07 & 0.60 & & 0.82 & 0.03 & 0.28 & 0.99 & 0 & 0.01 & 0.99 & 0.13 & 0 & 0.59 & 0.76 & 0.96 & 0.82 \\
\hline $\mathrm{Sa}$ & 0.92 & 0.10 & 0.76 & 0.86 & & 0.05 & 0.42 & 0.85 & 0.02 & 0.04 & 0.87 & 0.17 & 0 & 0.60 & 0.92 & 0.90 & 0.89 \\
\hline An & 0.07 & 0.04 & 0.01 & 0.03 & 0.05 & & 0.44 & 0.01 & 0 & 0.02 & 0.03 & 0.01 & 0 & 0.76 & 0.05 & 0 & 0.01 \\
\hline $\mathrm{Ag}$ & 0.64 & 0.12 & 0.38 & 0.27 & 0.66 & 0.37 & & 0.30 & 0.16 & 0.30 & 0.01 & 0.33 & 0 & 0.62 & 0.48 & 0.34 & 0.42 \\
\hline $\mathrm{Bl}$ & 0.86 & 0.11 & 0.59 & 0.98 & 0.89 & 0 & 0.22 & & 0.03 & 0.07 & 0.99 & 0.20 & 0 & 0.57 & 0.79 & 0.98 & 0.87 \\
\hline $\mathrm{Ha}$ & 0.26 & 0.77 & 0.45 & 0 & 0 & 0 & 0.01 & 0.05 & & 0.77 & 0 & 0.10 & 0.01 & 0 & 0.02 & 0.01 & 0.03 \\
\hline Ach & 0.20 & 0.61 & 0.47 & 0 & 0 & 0 & 0.02 & 0.04 & 0.70 & & 0.01 & 0.49 & 0.05 & 0.03 & 0.07 & 0.05 & 0.20 \\
\hline $\mathrm{Mn}$ & & & & & & & & & & & & 0.13 & 0 & 0.60 & 0.95 & 0.97 & 0.85 \\
\hline $\mathrm{Ll}$ & & & & & & & & & & & & & 0.43 & 0.10 & 0.20 & 0.20 & 0.46 \\
\hline $\mathrm{Cl}$ & & & & & & & & & & & & & & 0 & 0 & 0 & 0.01 \\
\hline Gp & & & & & & & & & & & & & & & 0.57 & 0.58 & 0.54 \\
\hline Su & & & & & & & & & & & & & & & & 0.86 & 0.89 \\
\hline S & & & & & & & & & & & & & & & & & 0.92 \\
\hline & & & & & & & & & & & & & & & & & \\
\hline
\end{tabular}

Note. complete dietary dissimilarity; low overlap; medium overlap; $\quad$ high overlap

**Abbreviations: Pine Marten - Mm; Raccoon Dog - Np; Red Fox — Vv; Tengmalm's Owl — Af; Tawny Owl — Sa; Sparrowhawk — An; Goshawk — Ag; Rough-legged Buzzard — Bl; White-tailed Eagle — Ha; Golden Eagle - Ach; Weasel — Mn; Eurasian Lynx — Ll; Grey Wolf - Cl; Pygmy Owl — Gp; Ural Owl — Su, Great Grey Owl - Sn; Eagle-Owl — Bb.

Shift in feeding habits and resource partitioning between vertebrate predators in relation to Wild Boar depopulation

While comparing the feeding habits of some predatory species before and after depopulation of Wild Boars it was revealed that the dietary composition of three species (the Raccoon Dog, White-tailed and Golden Eagles) out of 10 selected species changed significantly $(G=53.5-119.0, p<0.05)$ due to lower consumption of Wild Boar carrion and higher consumption of other food items (table 5). A little sifts in diets of other scavengers have also been noticed however these changes were not statistically significant. The Golden Eagle and White-tailed Eagle compensated for the lack of Wild Boar carrion by more frequent consumption of Cervids' carrion, and the Raccoon Dog started to consume Beaver (Castor fiber L.) carcasses.

Dietary overlaps between 10 selected species changed when comparing before and after depopulation - for 17 pairs of species dietary similarity increased, and for 23 pairs of 
species decreased, for 4 species was the same (table 4). Along that, the average value of the dietary similarity for selected species remained almost the same - 0.37 before 2013 versus 0.36 after 2013. The food niche breadth of predators became wider with the exception of the Pine Marten whose range of foods consumed decreased. Despite of revealed changes, the trophic structure of the community remained almost the same (fig. 4) with the exception of the goshawk who moved to the small mammal consumers' guild.

During the study we revealed that the most common 16 species of vertebrate predators in forests of Belarussian Paazerje during the cold season formed four trophic guilds: small mammal consumers, bird consumers, scavengers, and ungulate consumers. The guilds comprised species from different taxonomic groups and with different food niche breadth. Despite of the extremely high (>90\%) dietary overlaps within each guild the average dietary similarity for the whole community was fairly moderate -0.37 .

The highest dietary overlaps were found for the guild of small mammal consumers. However, reduction of an actual competition between them was possible due to a selection of different prey species. Voles genus Microtus, the Bank Vole, Myodes glareolus Schreber, 1780 , and mice genus Sylvaemus were preferential prey and caught with different frequency by different predatory species (tables $1-4$ ). Rodents have 3-5 year multiannual cycles in Belarus (Sidorovich, 2011), and periods of outbreaks alternates with periods of population declines. Predators react on changes in a small rodent abundance either with numerical responses (e. g. Weasel (Sidorovich, 2011)) or with functional responses (e. g. Rough-legged

Table 5. Dietary composition (\% BC) of vertebrate predators in the cold season in coniferous-smallleaved forests of Belarussian Paazerje, Northern Belarus, 2013-2019

\begin{tabular}{|c|c|c|c|c|c|c|c|c|c|c|}
\hline Food items & 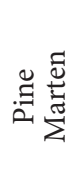 & $\begin{array}{l}\infty \\
0 \\
0 \\
\tilde{0} \\
\tilde{0} \\
\tilde{U} \\
\tilde{\mathscr{Z}}\end{array}$ & 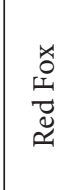 & 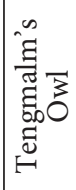 & 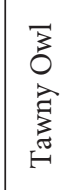 & 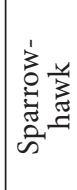 & 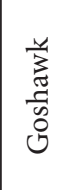 & 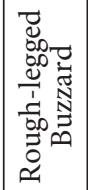 & 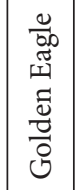 & 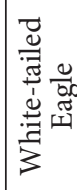 \\
\hline Invertebrates & 3.0 & 0.2 & 0.1 & 0.5 & - & - & - & 0.1 & - & - \\
\hline Fish & 0.2 & 3.1 & - & - & - & - & - & - & - & 26.9 \\
\hline Amphibians and reptiles & 1.7 & 4.3 & 0.2 & - & 10 & - & 0.1 & - & - & - \\
\hline Small insectivores & 5.9 & 5.4 & 0.4 & 1.3 & 13.7 & - & - & 0.9 & - & - \\
\hline Small rodents, among them: & 52.1 & 3.7 & 41.7 & 95.4 & 57.5 & _- & 28.8 & 88.2 & - & - \\
\hline Microtus voles & 17.5 & 3.3 & 29.0 & 73.1 & 19.5 & - & 10.9 & 80.9 & - & - \\
\hline Sylvaemus mice & 6.2 & 0 & 0.1 & 10.8 & 6.7 & - & 2.5 & 7.0 & - & - \\
\hline Bank Vole & 22.1 & 0.4 & 12.3 & 8.2 & 26.2 & - & 12.9 & 0.2 & - & - \\
\hline Water Vole & - & - & - & 0.4 & - & - & - & - & - & - \\
\hline Other small rodent spe & 6.3 & - & 0.3 & 2.9 & 5.1 & - & 2.5 & 0.1 & - & - \\
\hline Squirrel, muskrat and hedgehog & 6.3 & 0.2 & 8.7 & - & 4.9 & _ & 13.4 & 3.6 & - & _- \\
\hline Hares & 0.4 & 5.4 & 12.7 & _ & - & _ & - & 0.1 & 26.3 & 8.4 \\
\hline Beaver & - & - & 1.9 & - & - & - & - & - & - & - \\
\hline Roe Deer and Red Deer & - & - & - & - & - & - & - & - & - & - \\
\hline Elk & - & - & - & - & - & - & - & - & - & - \\
\hline Wild Boar & - & _- & - & - & - & _- & _- & - & - & - \\
\hline Small mustelids & 0.1 & - & - & - & 3.8 & - & 1.4 & 0.3 & - & - \\
\hline Medium-sized mustelids & - & 1.3 & - & - & - & - & 0.7 & - & 3.6 & 7.2 \\
\hline Red Fox and Raccoon Dog & - & 1.0 & - & - & - & - & - & - & 17.7 & 10.9 \\
\hline Domestic animals & - & 0.4 & - & - & - & - & 2.3 & - & 7.3 & - \\
\hline Carrion of wild animals, among them: & 19.8 & 56.8 & 28.7 & - & - & - & 0.6 & 6.8 & 26.3 & 37.2 \\
\hline Beaver & 0.5 & 20.5 & - & - & - & - & - & 1.2 & - & - \\
\hline Cervids & 19.3 & 33.3 & 23.4 & - & - & - & 0.6 & 5.5 & 22.1 & 31.2 \\
\hline Wild Boar & - & 3.0 & 5.3 & - & - & - & - & 0.1 & 4.2 & 6.0 \\
\hline Small birds & 4.4 & 2.8 & 0.9 & 2.9 & 3.6 & 100 & 23.2 & - & - & - \\
\hline Medium-sized and big birds & 4.0 & 3.2 & 2.9 & - & 6.5 & - & 29.5 & _ & 18.9 & 9.3 \\
\hline Bird eggs & 1.8 & 0.5 & - & - & - & - & - & - & - & - \\
\hline Seeds, fruits and vegetables & 0.3 & 9.2 & 1.8 & - & - & - & - & - & - & - \\
\hline Other & - & 2.5 & - & - & - & - & - & - & - & - \\
\hline $\begin{array}{l}\text { Number of food specimens }(\mathrm{n}) \text { in the analysed } \\
\text { samples }(\mathrm{m}), \mathrm{n}(\mathrm{m})\end{array}$ & $\begin{array}{l}181 \\
(87)\end{array}$ & $\begin{array}{c}305 \\
(198)\end{array}$ & $\begin{array}{c}381 \\
(127)\end{array}$ & $\begin{array}{l}104 \\
(83)\end{array}$ & $\begin{array}{l}342 \\
(70)\end{array}$ & $\begin{array}{c}93 \\
(43)\end{array}$ & $\begin{array}{l}108 \\
(65)\end{array}$ & $\begin{array}{c}211 \\
(123)\end{array}$ & $\begin{array}{c}48 \\
(48)\end{array}$ & $\begin{array}{c}77 \\
(77)\end{array}$ \\
\hline Levins' index $(B)$ of food niche breadth & 3.09 & 2.91 & 3.55 & 1.10 & 2.71 & 1.00 & 4.12 & 1.28 & 4.7 & 4.1 \\
\hline
\end{tabular}




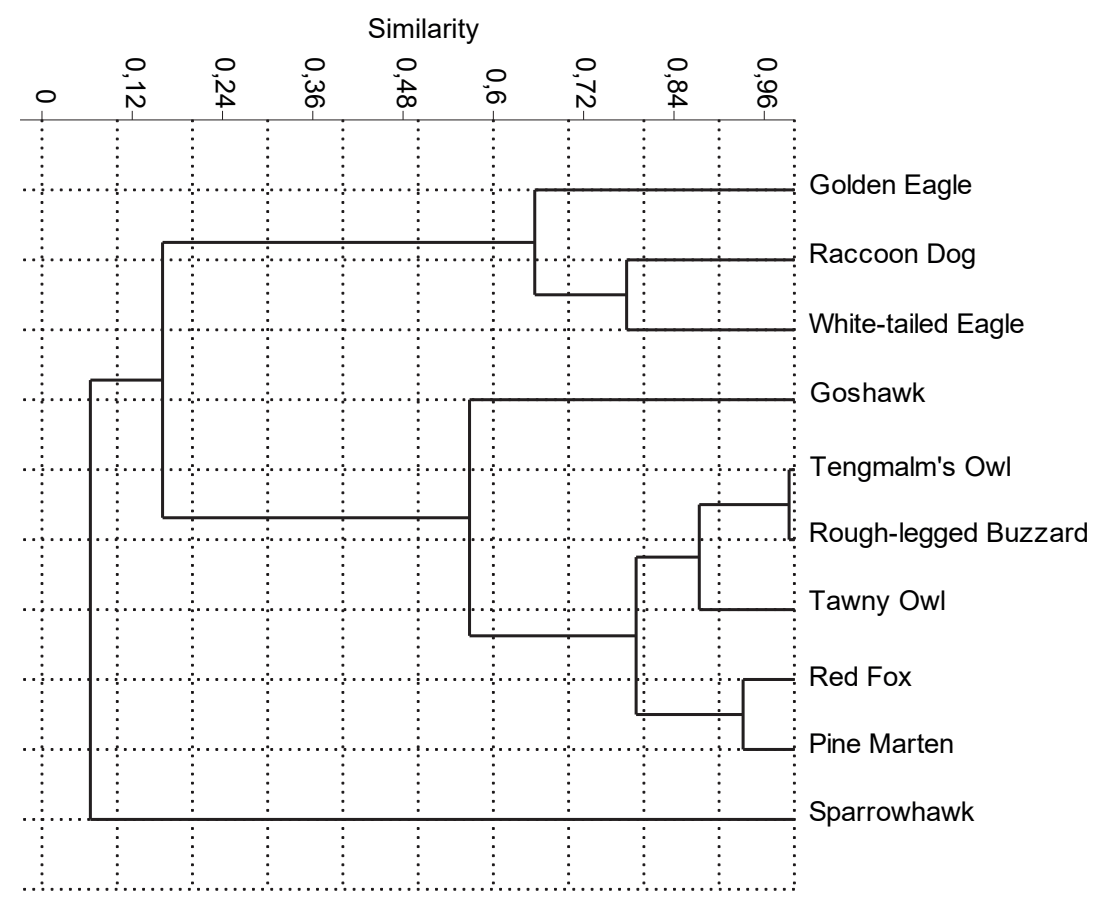

Fig. 4. Dietary similarity of 10 vertebrate predators in the cold season in Belarussian Paazerje, 2013-2019.

Buzzard (Sidorovich, 2016) or both (e. g. Red Fox (Sidorovich et al., 2006; Sidorovich et al., 2010). Another mechanisms of reduction of competition is a merge in daily activity and habitat use as it takes place for example for the Rough-legged Buzzard and Great Grey Owl (Ivanovskij, 2012).Thus, the trophic structure of the community is not static and shifts all the time. During the warm period ecological carrying capacity of the environment and prey accessibility is much higher than that in the cold season so it is much easier to find alternative food resources. That is why the cold season is the crucial period for the surviving for the most predatory species.

In the guild of bird consumers, the same patterns lead to a more efficient resource partitioning. Selection of different prey species was found for the Sparrowhawk and Gashawk (tables 1 and 2), and a different daily activity time is attributable for the Sparrowhawk and Pygmy Owl.

Kills of large predators such as the Wolf and Lynx are essential supply of carrion for scavengers (Sidorovich et al., 2000), so shift in the diet of large predators is the primeval cause of changes in resource partitioning between scavenging species. Scavengers cannot escape direct competition, and the scarcity of mammalian carrion may have negative consequences for their population dynamics. During our study we reveal that physical encounters between White-tailed and Golden Eagles near carrion took place quite often, while the rest scavengers fed on carrion without direct interference.

Anthropogenic disturbances often alter patterns of community functioning. Along that, how interacting species respond to these changes remains poorly understood. Usually resource scarcity leads to a greater trophic similarity due to more frequent utilization of remained resources. However, in our study, recent decrease in abundance of carrion in a result of depopulation of Wild Boars did not caused significant structural changes in the community although the dietary composition of all carrion consumers have been changed. The average dietary similarity in the community stayed almost the same showing compensatory mechanisms in resource partitioning in the community. 


\section{References}

Böhme, G. 1977. Zur Bestimmung quartärer Anuren Europas an Hand von Skelettelementen. Wissenschaftliche Zeitschrift der Humboldt-Universitat zu Berlin, Mathematish-Naturwissenschaftliche Reihe, 1977, 26, 283-300.

Brown, R., Ferguson, J., Lees, D. 1999. Tracks and Signs of the Birds of Britain and Europe. Christopher Helm Publishers Ltd., London, 1999, 1-232.

Debrot, S., Fivaz, G., Mermod, C., Weber, J. M. 1982. Atlas of hairs of European Mammals. Institute of Zoology of University of Neuchatel, Neuchatel, 1982, 1-208.

Cramp, S., Simmons, K. E. L. 1980. Handbook of the Birds of Europe, the Middle East, and North Africa: The Birds of the Western Palearctic. Oxford University Press, London, 1980. Vol. II, 1-696.

Grigyantz, R. B. 1993. The software for informational and search systems with data bases of full-text documents of the heterogeneous structure (ASPID/GT) with applications for the statistical analysis (ECOPROG). National Academy of Sciences of Belarus, the Computing Center, Minsk, 1993, 1-187 [In Russian].

Ivanovskij, V. V. 2012. Birds of prey of Belarusian Poozerie. VSU named after P. M. Masherov, Vitebsk, 2012, 1-209 [In Russian with English summary]. ISBN 978-985-517-357-2.

Ivanovskij, V. V., Sidorovich, V. E., Solovej, I. A. 2019. Trophic links between birds of prey and their competitors in wetlands during nesting period. Vestnik TvSU. Seria "Biology and Ecology", 2019, 2 (54), 44-58[In Russian with English summary].

Jaksic, F. M., Greene, H. W., Yanez, J. L. 1981. The guild Structure of a Community of Predatory Vertebrates in Central Chile. Oecologia, 1981, 49, 21-28.

Jedrzejewska, B., Jedrzejewski, W. 1998. Predation in Vertebrate Communities. The Bialowieza Primeval Forest as a Case Study. Springer, Berlin, 1998, 1-450.

Kataev, G. D., Okulova, N. M. 2007. Diet of terrestrial predators in vertebrate communities of Lapland reserve. Zoologicheskij Jurnal, 2007, 86 (1), 90-105 [In Russian].

Krebs, J. K. 1999. Ecological Methodology. Addison-Welsey Longman Inc., Oslo, 1999, 1-620.

Levins, R. 1968. Evolution in changing environments. Princeton Univ. Press, Princeton, 1968, 1-132.

März, R. 1987. Gewöll - und Rundfunkskunde [Prey Remnants in Pellets and Scats of Predators]. Akademie Verlag, Berlin, 1987, 1-288 [In German].

Matveev, A. V., Gurski, B. N., Levitskaja, R. I. 1988. Relief of Belarus. Nauka i Tehnika, Minsk, 1-233 [In Russian]. Pucek, Zd. 1981. Keys to Vertebrates of Poland Mammals. Polish Scientific Publishers, Warsaw, 1981, 1-367.

Reynolds, J. C., Aebischer, N. J. 1991. Comparison and quantification of carnivore diet by faecal analysis: a critique, with recommendations, based on a study of the Fox Vulpes vulpes. Mammal Review, 1991, 3, 97-122.

Sidorovich, V. E., Polozov, A. G., Lauzhel, G. O., Krasko, D. A. 2000. Dietary overlap among generalist carnivores in relation to the impact of the introduced Raccoon Dog Nyctereutes procyonoides on native predators in northern Belarus. Z. Saugetierkunde, 2000, 65, 271-285.

Sidorovich, V. E., Sidorovich, A. A., Izotova, I. A. 2006. Variations in the diet and population density of the Red FoxVulpes vulpes in the mixed wood-lands of northern Belarus. Mammalian Biology, 2006, 71 (2), 74-89.

Sidorovich, V. E., Sidorovich, A. A., Krasko, D. A. 2010. Effect of felling on Red Fox (Vulpes vulpes) and Pine Marten (Martes martes) diets in transitional mixed forest in Belarus. Mammalian Biology, 2010, 75, 399411.

Sidorovich, V. E. 2011. Analysis of vertebrate predator-prey community. Tesey, Minsk, 2011, 1-736.

Sidorovich, A. A. 2014. Methodology of a study of vertebrate predators: dietary investigation. Belarusian State University, Minsk, 1-88 [In Russian].

Sidorovich, V. E., Sidorovich, A. A., Solovej, I. A. 2016. Birds: Rough-legged buzzard Buteo lagopus. In: Sidorovich, V. E. Naliboki Forest. Land, Wildlife and Human. Chatyry chverci, Minsk, 2016, 2. Wild animals, 526-527.

Sokal, R. R., Rohlf, F. J. 1995. Biometry: The Principles and Practice of Statistics in Biological Research. W. H. Freeman and company, New York, 1995, 1-887.

Teerink, B. J. 1991. Hair of West-European Mammals. Cambridge University Press, Cambridge,1-224.

Received 17 January 2021

Accepted 3 March 2021 